\title{
Strategi Guru dalam Pembelajaran Sains di RA Nurul Ummi Pamenang Kecamatan Pamenang Kabupaten Merangin
}

\begin{tabular}{|c|c|}
\hline & $\begin{array}{c}\text { Karmila, Fithri Azni*, Fatimah AS } \\
\text { STKIP YPM Bangko, Jambi, Indonesia } \\
\text { *Coresponding Author: aznifithri9@gmail.com }\end{array}$ \\
\hline Article history & \multirow{8}{*}{$\begin{array}{l}\text { Abstrak: Penelitian ini dilatar belakangi oleh anak-anak di RA } \\
\text { Nurul Ummi Pamenang Kecamatan Pamenasng Kabupaten } \\
\text { Merangin terlihat tertarik sekali untuk belajar, antusias, semangat } \\
\text { dan aktif dalam mengikuti pembelajaran sains tersebut serta } \\
\text { terlihat kerjasama antara anak dan pendidik sangat baik, hal ini } \\
\text { dikarenakan strategi guru dalam pembelajaran sains di RA Nurul } \\
\text { Ummi Pamenang Kecamatan Pamenang sesuai dengan kemauan } \\
\text { anak dan tujuan pembelajaran gurupun tercapai. Tujuan } \\
\text { penelitian ini untuk mengetahui metode, alat dan bahan dan } \\
\text { kendala guru dalam pembelajaran sains di RA Nurul Ummi } \\
\text { Pamenang Kecamatan Pamenang Kabupaten Merangin. } \\
\text { Penelitian ini menggunakan Metode kualitatif dan pendekatan } \\
\text { yang digunakan adalah studi kasus. Teknik Pengumpulan data } \\
\text { yaitu dengan cara observasi, wawancara dan dokumentasi. } \\
\text { Informan penelitian } 4 \text { orang, yang diambil dengan tekhnik } \\
\text { proposive sampling. Teknik analisis data yaitu menggunkan } \\
\text { reduksi data, penyajian data dan penarikan kesimpulan/verifikasi } \\
\text { Teknik penjamin keabsahan data menggunakan kepercayan } \\
\text { (Credibility), Ketergantungan (Depandibility), Kepastian } \\
\text { (confermobility). Berdasarkan hasil analisis ditemukan metode } \\
\text { guru dalam pembelajaran sains di RA Nurul Ummi Pamenang } \\
\text { Kecamatan Pamenang Kabupaten Merangin yaitu dengan } \\
\text { mengajak anak untuk melakukan kegiatan bersama-sama dalam } \\
\text { pembelajaran sains tentang pengabungan warna, dengan } \\
\text { menggunakan strategi pembelajaran bermain bebas namun tetap } \\
\text { dengan arahan guru dan menggunakan metode pembelajaran } \\
\text { bermain melaui berekperimen. Sedangkan kendala yang dihadapi } \\
\text { dalam pembelajaran sains tentang pengabungan warna yaitu } \\
\text { faktor biaya, hal ini dikarenakan setiap anak mendapatkan } \\
\text { sepaket untuk melakukan pembelajaran sains pengabungan } \\
\text { warna. }\end{array}$} \\
\hline Dikirim: & \\
\hline 14-01-2022 & \\
\hline $\begin{array}{l}\text { Direvisi: } \\
\text { 16-01-2022 }\end{array}$ & \\
\hline $\begin{array}{l}\text { Diterima: } \\
17-01-2022\end{array}$ & \\
\hline Key words: & \\
\hline & \\
\hline & \\
\hline
\end{tabular}

\section{PENDAHULUAN}

Strategi untuk memberikan pembekalan yang optimal pada anak ,adalah didahului dengan memahami karakteristik dan tujuan guruan dan pembelajaran yang akan diterapkan kepada anak usia dini,termasuk dalam bidang pengembangan pembelajaran sains untuk anak, pemahaman dan penguasaan akan tujuan dan ruang lingkup guruan sains akan banyak membantu pengajaran dalam program pembelajaran anak usia dini yang dianggap tepat. Pengalaman belajar yang diperoleh anak dari lingkungan, melalui cara mengamati,meniru, dan bereksperimen yang berlangsung secara berulang-ulang, termasuk stimulasi yang akan mempengaruhi 
seluruh potensi dan kecerdasan anak. Oleh karena itu diperlukan upaya yang mampu memfasilitasi anak dalam masa tumbuh kembangnya berupa kegiatan guruan dan pembelajaran sesuai dengan usia, kebutuhan, dan minat anak.

Sains sangat berhubungan langsung dengan anak melalui proses-proses alam yang terjadi disekeliling anak. Pengenalan tentang sains hendaknya dilakukan sejak dini dengan kegiatan yang menyenangkan dan melalui pembiasaan agar anak mengalami proses sains secara langsung. Hal ini dilakukan agar anak tidak hanya mengetahui hasil saja tetapi juga dapat mengerti proses dari kegiatan sains yang dilakukannya. Pengenalan tentang sains hendaknya dilakukan sejak dini dengan kegiatan yang menyenangkan dan melalui pembiasaan agar anak mengalami proses sains secara langsung. Hal ini dilakukan agar anak tidak hanya mengetahui hasil saja tetapi juga dapat mengerti proses dari kegiatan sains yang dilakukannya.

Pembelajaran sains bagi anak usia dini dapat dilakukan didalam ruangan maupun diluar ruangan. Pengenalan sains untuk anak usia dini lebih ditekankan pada proses daripada produk dan untuk anak usia dini keterampilan proses sains hendaknya dilakukan secara sederhana sambil bermain. Kegiatan sains memungkinkan anak melakukan eksplorasi terhadap berbagai benda, baik hidup maupun benda tak hidup yang ada di sekitarnya. Anak belajar menemukan gejala benda dan gejala peristiwa dari benda-benda tersebut, kemampuan sains pada anak usia dini, memiliki peranan yang sangat penting dalam membantu meletakkan dasar kemampuan dan pembentukkan sumber daya menusia yang diharapkan. Bedasarkan hasil observasi di RA Nurul Ummi Pamenang Kecamatan Pamenang bahwa didalam pembelajaran sains anak-anak terlihat tertarik sekali untuk belajar, antusias, semangat dan aktif dalam mengikuti pembelajaran sains tersebut. Didalam pembelajaran sains tersebut terlihat kerjasama antara anak dan guru sangat baik, hal ini dikarenakan strategi guru dalam pembelajaran sains di RA Nurul Ummi Pamenang Kecamatan Pamenang sesuai dengan kemauan anak dan tujuan pembelajaran gurupun tercapai.

Maka dari itu berdasarkan latar belakang yang dapat dilihat diatas, peneliti tertarik untuk mengetahui hal-hal yang telah dilakukan guru dalam pembelajran sains.

\section{KAJIAN TEORI}

Pembelajaran adalah segala upaya yang dilakukan oleh guru yaitu guru menggunakan sumber belajar agar terjadi proses belajar pada anak yang menimbulkan adanya hasil belajar (Sutarto \& Syarifuddin, 2013; Ruwaidah, 2021). Manusia terlibat dalam sistem pengajaran yang terdiri dari guru dan anak. Material, meliputi buku-buku, papan tulis, media pembelajaran (Kartini, 2021). Fasilitas, meliputi ruang kelas dan perlengkapanya sedangkan prosedur, meliputi jadwal, metode pembelajaran dan evaluasi.

Tujuan pembelajaran menggambarkan proses dan hasil belajar yang di harapkan dicapai oleh anak sesuai kompetensi dasar (Rusman; 2012:6; Sutarto \& Syarifuddin, 2013). Meski para ahli memberikan rumusan tujuan pembelajaran yang beragam, tetapi semuanya menunjuk pada esensi yang sama, bahwa : tercapainya perubahan perilaku atau kompetensi pada anak setelah mengikuti kegiatan pembelajaran; Tujuan dirumuskan dalam bentuk pernyataan atau deskripsi yang spesifik. Perumusan tujuan pembelajaran harus diwujudkan dalam bentuk tertulis. 
Hal ini mengandung implikasi bahwa setiap perencanaan pembelajaran seyogyanya dibuat secara tertulis.

Metode pembelajaran juga bisa diartikan sebagai cara yang digunakan untuk menimplementasikan rencana yang sudah disusun dalam bentuk kegiatan nyata dan praktis untuk mencapai tujuan pembelajaran (Djamarah, 2010:19)

Menurut Depdiknas (2006:35) Ada beberapa contoh metode pembelajaran Guruan Anak Usia Dini antara lain: 1) Metode pembelajaran bermain. b) Metode pembelajaran melalui bercerita, c) Metode pembelajaran melalui bernyanyi, d) Metode pembelajaran terpadu e) Metode pembelajaran pemberian tugas (Sari \& Aisyah, 2021), f )Metode pembelajaran karya wisata g) Metode pembelajaran bercakap-cakap h) Metode pembelajaran sentra dan lingkaran, i) Metode pembelajaran quantum teaching.

Amin dalam Nugraha (2005:3) pengertian sains adalah sebagai bidang ilmu alamiah, degan ruang lingkup zat dan energy baik yang tersapat dalam makhluk hidup maupun makhluk tak hidup dengan lebih banyak mendiskusikan tentang alam. Didalam proses perkembangan sains pada anak usia dini harus melalui beberapa tahapan, seperti yang tetuang dalam Nugraha (2005:125) yaitu:

1. Mengamati

Mengamati yaitu anak melibatkan kombinasi dari beberapa atau seluruh indra. Didalamnya terdapat kegiatan melihat, mendengarkan, meraba, mencicipi, mencium, merasa. Dengan kegiatan ini anak terlibat langsung dengan lingkungan sekitar dan benda-benda yang ada disekelilingnya.

2. Mengklasifikasi atau mengelompokkan.

Merupakan suatu sistematika untuk mengatur obyek-obyek kedalam sederetan kelompok tertentu. Anak dapat belajar mencari persamaan dan perbedaan objekobjek.

3. Menafsirkan atau meramalkan

Yaitu suatu keterampilan membuat perkiraan tentang sesuatu yang belum terjadi

4. Mengkomunikasikan

Yaitu anak dalam melaporkan hasil kegiatan sainsnya kedalam bentuk tulisan, gambar, lisan dan sebagainya, serta penggunaan alat ukur dengan teliti dan cermat.

Tujuan pembelajaran sains bagi anak usia dini menurut Nugraha (2005:31) antara lain: a) Agar anak-anak memiliki kemampuan memecahkan masalah yang dihadapai melalui penggunaan metode sains. Agar anak memiliki sikap ilmiah, b) Agar anak mendapat pengetahuan dan informasi ilmiah yang lebih baik dan dapat dipercaya, c) Agar anak lebih berminat dan tertarik dalam menghadapi sains

Kegiatan bermain sains sangat penting diberikan untuk anak usia dini karena multi manfaat, yakni dapat mengembangkan kemampuan ekplorasi dan investigasi, yaitu kegiatan untuk mengamati dan menyelidiki objek serta penomena alam, mengembangkan keterampilan proses sains dasar, seperti melakukan pengamatan, mengukur, mengkomunikasikan hasil pengamatan dan lainnya. Sains juga mengembangkan rasa ingin tahu, rasa senang dan mau melakukan kegiatan inkuiri atau penemuan. Selain itu sains bisa membuat anak jadi memahami pengetahuan tentang berbagai benda, baik itu ciri, struktur maupun fungsinya.

Pembelajaran sains untuk anak usia dini memiliki beberapa manfaat yang bisa diperoleh jika kita mengenalkan sains pada anak dari kecil itu akan melatih anak 
bereksperimen dengan melaksanakan beberapa percobaan, memperkaya wawasan anak untuk selalu ingin mencoba dan mencoba. Sehingga anak terdorong menjadi kreatif, inisiatif, imajinatif, berpikir terstruktur terhadap aturan, dan jujur akan sebuah hasil.

\section{METODE PENELITIAN}

\section{Pendekatan dan Metode}

Dalam penelitian ini menggunakan pendekatan deskriptif kualitatif adalah untuk membuat pengambaran secara sistematis, faktual, dan akurat mengenai fakta dan sifat populasi atau daerah tertentu. Penelitian ini digunakan untuk mengetahui strategi guru dalam pembelajaran sains di RA Nurul Ummi Pamenang Kecamatan Pamenang Kabupaten Merangin. Menurut Darmadi (2014:290) Ada 5 (lima) jenis penelitian kualitatif, yaitu: Biografi, Fenomelogi, Grounded theory, Etnografi, dan Studi Kasus. Dalam hal ini penelitian yang digunakan adalah metode penelitian studi kasus (case study), yaitu: Studi yang mengeksplorasi suatu masalah dengan batasan terpencil, memiliki pengembalian data yang mendalam, dan menyertakan berbagai sumber informasi (Darmadi,2014:291).

\section{Latar dan Entry Penelitian}

Latar atau lokasi penelitian ini dilakukan di RA Nurul Ummi Pamenang Kecamatan Pamenang Kabupaten Merangin. Yang beralamat di Jalan Keroya Kecamatan Pamenang Kabupaten Merangin. Dari jalan Lintas Sumatera Pusat Kota Bangko ke Kecamatan Pamenang 28 KM, dari jalan lintas Sumatra kelokasi RA Nurul Ummi Pamenang Kecamatan Pamenang Kabupaten Merangin 18 KM.

Entri merupakan suatu cara atau langkah peneliti untuk bisa masuk kedalam penelitian. Sejalan dengan Moleong (2017:401) "entri merupakan suatu langkah atau cara dimana peneliti untuk bisa masuk kedalam suatu latar penelitian”. Penelitian ini berusaha untuk menghindari segala kemungkinaan yang dapat menghambat kegiatan penelitian. Sebelum penelitian dimulai, peneliti memelukan izin mengadakan penelitian, kontak dengan daerah yang menjadi latar penelitian melalui surat atau melalui orang sebagai penghubung ataupun secara resmi dengan surat melalui jalur pemerintahan.

Setelah mendapatkan izin penelitian, maka peneliti mengadakan pendekatan dengan pengurus RA yang dijadikan sebagai informan. Melalui pendekatan ini disampaikan, maksud penelitian, prosedur penelitian, data, dan perkiraan waktu yang dibutuhkan untuk mengumpulkan data dengan cara yang telah ditentukan. Pada tahap berikutnya adalah kegiatan mengumpulkan data meneksplorasi berbagai keterangan yang dibutuhkan, atau sesuai panduan observasi, wawancara dan dokumentasi.

Untuk itu, dalam hal ini peneliti adalah sebagai instrument kunci (Key Instrument), partisipasi penuh sekaligus pengumpul data, sedangkan instrumen yang lain adalah sebagai penunjang

\section{Teknik Pengumpulan Data}

\section{a. Observasi}

Observasi merupakan cara pengumpulan data yang dilakukan secara langsung dalam pengamatan dan pencatatan secara sistematis terhadap objek yang akan diteliti. Observasi dilakukan oleh peneliti dengan cara pengamatan dan pencatatan mengenai pelaksanaan pembelajaran. Observasi akan dilakukan pada Strategi guru 
dalam pembelajaran sains di RA Nurul Ummi Pamenang Kecamatan Pamenang Kabupaten Merangin..

Dalam pelaksanaan observasi partisipan lebih memfokuskan pada Strategi guru dalam pembelajaran sains di RA Nurul Ummi Pamenang Kecamatan Pamenang Kabupaten Merangin dengan menggunakan alat observasi yaitu panduan observasi. Untuk mendapatkan data hasil observasi peneliti terjun langsung di RA Nurul Ummi Pamenang Kecamatan Pamenang Kabupaten Merangin dengan membuat catatan lapangan sesuai waktu, tempat, nama informan dan kejadian yang terjadi. Data yang dikumpulkan yaitu berupa kegiatan-kegiatan yang dilakukan guru. Yang berkenaan dengan strategi guru dalam pembelajaran sains, dalam bentuk catatan lapangan.

b. Wawancara

Wawancara adalah percakapan dengan maksud tertentu. Maksud digunakannya wawancara antara lain adalah (a) mengkonstruksi mengenai orang, kejadian, kegiatan organisasi, perasaan, motivasi, tuntutan, kepedulian dan lain-lain, (b) mengkonstruksikan kebulatan-kebulatan demikian yang dialami masa lalu.

Tujuan dari wawancara adalah mendapatkan informasi yang mana pewawancara mengajukan pertanyaan dan harus dijawab orang yang diberikan pertanyaan atau orang yang diwawancarai. Langkah pertama penelitian ini adalah peneliti melakukan wawancara dengan nara sumber yaitu Kepala Sekolah, dua orang guru dan guru pembantu RA Nurul Ummi Pamenang Kecamatan Pamenang Kabupaten Merangin.

c. Dokumentasi

Teknik Dokumentasi, digunakan untuk mengumpulkan data dari sumber non insani, sumber ini terdiri dari dokumen dan rekaman (record). Rekaman (record) adalah setiap tulisan atau pernyataan yang dipersiapkan oleh atau untuk individual atau organisasi dengan tujuan membuktikan adanya suatu peristiwa atau memenuhi accounting. Sedangkan Dokumen adalah setiap bahan tertulis ataupun film yang digunakan untuk mengacu atau bukan selain rekaman, yaitu tidak dipersiapkan secara khusus untuk tujuan tertentu (Moleong, 2017; Syarifuddin dkk, 2021)

\section{Informan Peneliti}

Dalam penelitian ini menggunakan teknik penelitian purposive sampling. Purposive sampling adalah salah satu teknik sampling non random sampling dimana peneliti menentukan pengambilan sampel dengan cara menentukan ciri-ciri khusus yang sesuai dengan tujuan penelitian sehingga diharapkan dapat menjawab pertanyaan peneliti

Menurut Sugiyono (2015:85), "purposive sampling adalah teknik pengambilan sampel sumber data dengan pertimbangan tertentu ini, misalnya orang tersebut dianggap paling tahu tentang apa yang kita harapkan, atau dia sebagai penguasa sehingga akan mempermudah peneliti menjelajahi objek atau situasi yang diteliti”. Dalam proses penelitian ini, penulis menentukan yang akan menjadi informan penelitian ini adalah Bunda Maisarah,S.Pd.I Selaku Kepala sekolah, Bunda Siti Zuraida,S.Pd selaku guru, Bunda Samratul Fiqria,S.Sos selaku guru dan Bunda Hamsiyah selaku guru pembantu di RA Nurul Ummi Pamenang Kecamatan Pamenang Kabupaten Merangin 


\section{Teknik Analisis Data}

Analisis data kualitatif bersifat induktif, yaitu analisis berdasarkan data yang diperoleh. Menurut Sugiyono (2015:244), analisis data dilapangan menggunakan model Miles \& Huberman analisis terdiri dari tiga alur kegiatan yang terjadi secara bersamaan yaitu: reduksi data, penyajian data, penarikan kesimpulan/verifikasi.

Mengenai ketiga alur tersebut secara lebih lengkapnya adalah sebagai berikut:

\section{a. Reduksi Data}

Reduksi data diartikan sebagai proses pemilihan, pemusatan perhatian pada penyederhanaan, pengabstrakan, dan transformasi data kasar yang muncul dari catatan-catatan tertulis di lapangan. Reduksi data berlangsung terus-menerus selama proyek yang berorientasi penelitian kualitatif berlangsung. Antisipasi akan adanya reduksi data sudah tampak waktu penelitiannya memutuskan (seringkal tanpa disadari sepenuhnya) kerangka konseptual wilayah penelitian, permasalahan penelitian, dan pendekatan pengumpulan data mana yang dipilihnya. Selama pengumpulan data berlangsung, terjadilan tahapan reduksi selanjutnya (membuat ringkasan, mengkode, menelusur tema, membuat gugusgugus, membuat partisi, membuat memo). Reduksi data/transformasi ini berlanjut terus sesudah penelian lapangan, sampai laporan akhir lengkap tersusun. peringkat, tetapi tindakan ini tidak selalu bijaksana.

\section{b. Penyajian Data}

Miles \& Huberman membatasi suatu penyajian sebagai sekumpulan informasi tersusun yang memberi kemungkinan adanya penarikan kesimpulan dan pengambilan tindakan. Mereka meyakini bahwa penyajian-penyajian yang lebih baik merupakan suatu cara yang utama bagi analisis kualitatif yang valid, yang meliputi: berbagai jenis matrik, grafik, jaringan dan bagan. Semuanya dirancang guna menggabungkan informasi yang tersusun dalam suatu bentuk yang padu dan mudah diraih. Dengan demikian seorang penganalisis dapat melihat apa yang sedang terjadi, dan menentukan apakah menarik kesimpulan yang benar ataukah terus melangkah melakukan analisis yang menurut saran yang dikisahkan oleh penyajian sebagai sesuatu yang mungkin berguna.

\section{c. Menarik Kesimpulan/Verifikasi}

Penarikan kesimpulan menurut Miles \& Huberman hanyalah sebagian dari satu kegiatan dari konfigurasi yang utuh. Kesimpulan-kesimpulan juga diverifikasi selama penelitian berlangsung. Verifikasi itu mungkin sesingkat pemikiran kembali yang melintas dalam pikiran penganalisis (peneliti) selama ia menulis, suatu tinjauan ulang pada catatan-catatan lapangan, atau mungkin menjadi begitu seksama dan menghabiskan tenaga dengan peninjauan kembali serta tukar pikiran di antara teman sejawat untuk mengembangkan kesepakatan intersubjektif atau juga upaya-upaya yang luas untuk menempatkan salinan suatu temuan dalam seperangkat data yang lain. Singkatnya, makna-makna yang muncul dari data yang lain harus diuji kebenarannya, kekokohannya, dan kecocokannya, yakni yang merupakan validitasnya. Kesimpulan akhir tidak hanya terjadi pada waktu proses pengumpulan data saja, akan tetapi perlu diverifikasi agar benar-benar dapat dipertanggung jawabkan.

\section{Teknik Penjamin Keabsahan Data}

Uji keabsahan data dalam penelitian sering hanya ditekankan pada uji validaltas dan reabilitas. Validalitas merupakan derajat ketepatan antara data yang 
terjadi pada objek penelitian dengan daya yang dapat dilaporlan oleh peneliti. Sedangkan valid adalah data yang tidak berbeda antara data yang dilaporkan oleh peneliti dengan data yang sesungguhnya terjadi pada objek penelitian (Sugiyono, 2015:361).

Keabsahan data dilakukan untuk membuktikan apakah penelitian yang dilakukan benar-benar merupakan penelitian ilmiah sekaligus untuk menguji data yang diperoleh. Uji keabsahan data dalam penelitian kualitatif meliputi credibility, transferability, dependability, dan confirmability (Sugiyono, 2015:364). Agar data dalam penelitian kualitatif dapat dipertanggungjawabkan sebagai penelitian ilmiah perlu dilakukan uji keabsahan data.

\section{HASIL DAN PEMBAHASAN}

\section{Hasil Penelitian}

Berdasarkan hasil dari penelitian tentang Strategi Guru Dalam Pembelajaran Sains di RA Nurul Ummi Pamenang Kecamatan Pamenang Kabupaten Merangin peneliti menemukan beberapa temuan khusus diantaranya yaitu :

a. Metode guru dalam pembelajaran sains di RA Nurul Ummi Pamenang Kecamatan Pamenang Kabupaten Merangin.

Hasil wawancara yang dilakukan pada hari Kamis, 25 Juni 2021 Pukul 08.00 WIB, terhadap informan I yaitu Bunda Maisarah, S.P.d.I selaku kepala sekolah RA Nurul Ummi Pamenang Kecamatan Pamenang Kabupaten Merangin, dengan transkip wawancara:

metode guru dalam pembelajaran sains disini dengan cara melibatkan anak dengan cara mengajak mereka melakukan hal-hal yang berkaitan dengan sains. Dengan menggunakan metode bermain bebas akan tetapi tetap mengikuti arahan dari guru dan dengan menggunkan metode pembelajaran bermain dengan berekperimen.

Dari hasil wawancara diatas dapat disimpulkan bahwa metode guru dalam pembelajaran sians yaitu dilakukan bersama-sama anak didik, melakukan preaktek langsung dengan kegiatanya dengan cara berekperimen.

Hasil wawancara yang dilakukan pada hari Kamis, 25 Juni 2021 Pukul 09.00 WIB, terhadap informan II yaitu Siti Zuraida,S.Pd selaku guru RA Nurul Ummi Pamenang Kecamatan Pamenang Kabupaten Merangin, dengan transkip wawancara:

dalam pembelajaran sains kami disini mengajak anak untuk melakukan kegiatan bersama sambil memperaktekkan contohnya mengabungkan warna...dibeberapa gelas masing-masing terdapat satu warna..setelah itu dicampur nanti apa yang terjadi anak akan melihat warna yang berubah...

Dari hasil wawancara diatas dapat disimpulkan bahwa metode guru dalam pembelajaran sains yaitu dilakukanya bersama-sama anak didiknya, agar anak didik bisa senang dan paham tentang sains tentang pengabungan warna.

Hasil wawancara yang dilakukan pada hari Sabtu, 27 Juni 2021 Pukul 09.00 WIB, terhadap informan III yaitu Samratul Fiqria,S.Sos selaku guru RA Nurul Ummi Pamenang Kecamatan Pamenang Kabupaten Merangin, dengan transkip wawancara: 
metode kita disini dalam pembelajaran sains anak kita ajak bersama-sama untuk mencoba sesuatu, nanti sama anak dipraktekkan seperti mengabung warna.

Hasil observasi dilapangan bahwa ketika pemeblajaran sains yang dikemas dalam bentuk ekperimen, tidak terelakkan lagi jika anak-anak akan riyuh dan aktif ketika melihat warna-warna tersebut.

Hasil wawancara yang dilakukan pada hari Minggu, 28 Juni 2021 Pukul 09.30 WIB, terhadap informan IV yaitu Hamsiyah selaku guru bantu di RA Nurul Ummi Pamenang Kecamatan Pamenang Kabupaten Merangin, dengan transkip wawancara:

guru mengajak anak untuk bersama-sama melakukan praktek pembelajaran seperti memcampurkan warna, dimana guru dengan menggunakan metode bermain bebas akan tetapi tetap mengikuti arahan dari guru dan dengan menggunakan metode pembelajaran bermain dengan bereksperimen.

Dari hasil wawancara dapat di simpulkan bahwa metode guru dalam pembelajaran sains yaitu melakukan praktek bersama-sama anak dengan menggunakan metode pembelajran bermain dengan berekperimen.

Hasil observasi dilapangan bahwa anak melakukan pembelajaran sains dengan guru, terlihat aktif dan penuh dengan kekaguman ketika melihat warna-warni didalam air.

Dari hasil wawancara diatas dapat disimpulkan secara menyeluruh bahwa metode guru dalam pembelajaran sains di RA Nurul Ummi Pamenang Kecamatan Pamenang Kabupaten Merangin yaitu dengan menggunkan metode pembelejaran bermain melaui ekperimen/percobaan yaitu dengan berekperimen pengabungan warna.

Dari hasil observasi diatas dapat disimpulkan secara menyeluruh bahwa didalam observasi metode guru dalam pembelajaran sians di RA Nurul Ummi Pamenang Kecamatan Pamenang Kabupaten Merangin, kegiatan yang dilakukan guru bersama anak didiknya, membuat anak didik tersebut menjadi lebih aktif dan antusias dalam pembelajaran sains.

\section{b. Kendala guru dalam pembelajaran sains di RA Nurul Ummi Pamenang Kecamatan Pamenang Kabupaten Merangin}

Hasil wawancara yang dilakukan pada hari Kamis, 25 Juni 2021 Pukul 08.00 WIB, terhadap informan I yaitu Bunda Maisarah, S.P.d.I selaku kepala sekolah RA Nurul Ummi Pamenang Kecamatan Pamenang Kabupaten Merangin, dengan transkip wawancara:

kendalanya masalah peralatan dan perlengkapan. Bukan karena tidak ada yang jual tetapi karena faktor biaya. Nah,,,kalo kita menyuruh anak membawa terkadang orangtua ada yang merasa keberatan. Kalo kita siapkan dari sini biayanya bagaimana. Kalo hanya menyiapkan sample saja bisa tapi kan jadi g menarik kalo anak hnaya melihat. Akan lebih baik kalo anak juga ikut memperagakan/mempraktekkan

Dari hasil wawancara diatas dapat disimpulkan bahwa kendala guru dalam pembelajaran sains di RA Nurul Ummi Pamenang Kecamatan Pamenang Kabupaten merangin yaitu faktor biaya. 
Hasil observasi dilapangan bahwa anak melakukan ekperimen/percobaan dilakukan dengan cara masing-masing anak mendapatkan bahan percobaan, dan setelah guru mempraktekkan, anak memperhatikan setelah itu anak yang mempraktekkannya kembali, maka dari itu menelan banyak biaya.

Hasil wawancara yang dilakukan pada hari Kamis, 25 Juni 2021 Pukul 09.00 WIB, terhadap informan II yaitu Siti Zuraida,S.Pd selaku guru RA Nurul Ummi Pamenang Kecamatan Pamenang Kabupaten Merangin, dengan transkip wawancara:

peralatan dan perlengkapan dikarenakan masing-masing anak mendapatkan sepaket peralatan dan perlengkapan percobaan maka dibutuhkan perlengkapan dan peralatan sesuai dengan jumlah anak sehingga membutuhkan biaya yang banyak juga..

Hasil wawancara diatas dapat disimpulkan bahwa didalam strategi pembelajaran sains tentang pengabungan warna diperlukan peralatan dan perlengkapan yang banyak dikarenakan masing-masing anak akan melakukan percobaan tersebut sehingga membutukan biaya yang banyak juga.

Hasil observasi dari wawancara diatas adalah banyaknya biaya untuk melakukan percobaan dalam pembelajaran sains tentang pengabungan warna sehingga membuat kendala di RA Nurul Ummi Pamenang Kecamatan Pamenang Kabupaten Merangin ketika pembelajran tersbut.

Wawancara yang dilakukan pada hari Sabtu, 27 Juni 2021 Pukul 09.00 WIB, terhadap informan III yaitu Samratul Fiqria selaku guru RA Nurul Ummi Pamenang Kecamatan Pamenang Kabupaten Merangin, dengan transkip wawancara:

peralatan dan bahan. Kadang ada kita minta anak bawa, kadang ya kita siapain..ini karena faktor biaya

Hasil dari wawancara diatas adalah untuk mendapatkan peralatan dan perlengkapan yang cukup maka dibutukan biaya untuk mebelinya, dikarenakan biaya tidak mecukupi maka terjadilah kendala dalam pembelajaran sains tentang pengabungan warna.

Hasil observasi dari wawancara diatas adalah masing-masing anak mendapatkan sepaket peralatan dan perlengkapan dalam pembelajaran sins tentang pengabungan warna, sehingga menimbulkan kendala yang membutuhkan biaya banyak.

Kesimpulan wawancara diatas secara menyeluruh bahwa kendala guru dalam pembelajaran sains di RA Nurul Ummi Pamenang Kecamatan Pamenang Kabupaten Merangin adalah dkarenakan sitiap anak memutuhkan peralatan dan perlengkapan di pemebalajaran sains dalam pengabungan warna maka dana untuk mengadakan peralatan dan perlengkapan tersebut tidaklah sedikit, sehingga hal ini menimbulkan kendala bagi RA Nurul Ummi Pamenang Kecamatan Pamenang dalam pembelajaran sains tentang penabungan warna.

Kesimpulan obsevasi wawancara diatas secara menyeluruh adalah banyaknya biaya yang digunakan dalam pembelajaran sains tentang pengabungan warna hal ini menjadikan kendala guru dalam pembelajaran sains di RA Nurul Ummi Pamenang Kecamatan Pamenang Kabupaten merangin. 


\section{PEMBAHASAN}

\section{a. Metode guru dalam pembelajaran sains di RA Nurul Ummi Pamenang Kecamatan Pamenang Kabupaten Merangin.}

Hamalik (2003:57) menyatakan metode adalah cara atau seperangkat cara, jalan dan teknik yang digunakan oleh guru dalam proses pembelajaran agar anak dapat mencapai tujuan pembelajaran atau kompetensi tertentu. Menurut Kamus Besar Bahasa Indonesia (KBBI), Metode yaitu cara teratur yang digunakan untuk melaksanakan suatu pekerjaan agar tercapai sesuai dengan yang dikehendaki; cara kerja yang bersistem untuk memudahkan pelaksanaan suatu kegiatan guna mencapai tujuan yang ditentukan.

Suamiati (2009:11) menentukan metode atau kegiatan belajar meruapakan langkah yang penting dalam menunjang keberhasilan pencapaian tujuan. Kegiatan itu harus disesuaikan dengan tujuan. Dalam menentapkan kegiatan belajar guru harus menetapkan kegiatan mana yang perlu dan tidak perlu dilakukan.

Berdasarkan pembahasan di atas metode guru dalam pembelajaran sains di RA Nurul Ummi Pamenang Kecamatan Pamenang Kabupaten Merangin adalah dengan melakukan kegiatan bersama-sama anak didik dengan menggunakan metode pembelajaran bermain sambil bereksperimen dimana anak-anak melakukan kegiatan dengan peralatan dan perlengkapan yang disediakan oleh guru yang tentunya anak tetap mendapatkan arahan dari guru.

\section{b. Kendala guru dalam pembelajaran sains di RA Nurul Ummi Pamenang Kecamatan Pamenang Kabupaten Merangin.}

Menurut Kamus Besar Bahasa Indonesia (KBBI) Kendala adalah hambatan atau rintangan, yang berarti masalah yang dihadapi pada saat pelaksanaan kegiatan atau program yang sedang berlangsung.

Didalam wawancara dengan informan, metode guru dalam pembelajaran sains di RA Nurul Ummi Pamenang Kecamatan Pamenang Kabupaten Merangin, mempunyai kendala dalam faktor biaya. Hal ini dikarenakan dalam pemebelajaran sains tentang pengabungan warna masing-masing anak mndapatkankan peralatan dan perlengkapan yang akan mereka gunakan untuk mempraktekkan penggabungan warna.

\section{KESIMPULAN}

Dari hasil penelitian dan wawancara yang telah dilakukan selama penelitian dan pembahasan dapat diambil kesimpulan sebagai berikut:

1. Metode guru dalam pembelajaran sains di RA Nurul Ummi Pamenang Kecamatan Pamenang Kabupaten Merangin yaitu dengan mengajak anak untuk melakukan kegiatan bersma-sama, dengan menggunakan metode pembelajaran bermain sambil ekperimen akan tetapi tetap dalam arahan guru,

2. Kendala guru dalam pembelajaran sains di RA Nurul Ummi Pamenang Kecamatan Pamenang Kabupaten merangin yaitu terkendala masalah biaya, yang mana perlengkapan dan peralatan dalam kegiatan penggabungan warna dibutuhkan masing-masing anak. Ketika pembelajaran berlangsung anak mendapatkan sepaket peralatan dan perlengkapan tersebut. Hal ini membutuhkan banyak perlengkapan dan peralatan yang banyak sehingga membutuhkan biaya yang banyak pula. 


\section{DAFTAR PUSTAKA}

Darmadi, Hamid. (2014). Metode Penelitian Pendidikan Sosial. Bandung: Alfabeta

Depdiknas . (2006). Pedoman pembelajaran di TK, Jakarta

Djamarah, Syaiful Bahri. (2010). Strategi Belajar Mengajar. Jakarta . Rieneka Cipta

Hamalik, Oemar. (2003). Kurikulum Dan Pembelajaran, Jakarta : PT Bumi Aksara

Kartini, K., Andari, K. D. W., Bua, M. T., Bua, A. T., Satya, A. F., Rasmawati, R., ... \& Ariansyah, A. (2021). Pembuatan Media Belajar Sains Sederhana bagi Guru Sekolah Dasar di Kota Tarakan. Bima Abdi: Jurnal Pengabdian Masyarakat, 1(2), 77-82.

KBBI, (2016). Kamus Besar Bahasa Indonesia (KBBI). (online). Available at: http://kbbi.web.id/rehabititaion (diakses 21 Juni 2021)

Moleong, Lex, (2017). Metodologi Penelitian Kualiatif. Bandung: PT. Remaja Rosdakarya.

Nugraha, Ali. (2005). Pengembangan Pembelajaran Sains Pada Anak Usia Dini. Jakarta: Depdiknas

Rusman. (2012). Model-Model Pembelajaran: Mengembangkan Profesionalisme Guru. Jakarta.. Rajawali Pers PT RajaGrafindo Persada.

Ruwaidah, R. (2021). Penerapan Metode Demonstrasi untuk Meningkatkan Hasil Belajar Siswa pada Mata Pelajaran Informatika Materi Operasi Dasar Komputer di SMAN 4 Kota Bima Kelas X MIPA 1 Semester Ganjil Tahun Pelajaran 2020/2021. Jurnal Pendidikan dan Pembelajaran Indonesia (JPPI), 1(2), 177189.

Sari, F. F., \& Aisyah, S. (2021). Pengaruh Metode Pemberian Tugas terhadap Hasil Belajar Matematika. JagoMIPA: Jurnal Pendidikan Matematika dan IPA, 1(2), 84-98.

Sugiyono. (2015). Metode Penelitian Pendidikan (pendekatan Kuantitatif, kualitatif $R \& D)$. Bandung: Alfabeta

Sumiati \& Asra. (2009). Metode pembelajaran. Bandung. CV Wacana Prima

Sutarto, S., Pd, M., Syarifuddin, S. P., \& Pd, M. (2013). Desain Pembelajaran Matematika. Yogyakarta: Samudra Biru.

Syarifuddin, S., Nugroho, P. B., Fadhli, M., Murtalib, M., Mutmainah, M., Muchlis, M., ... \& Hadi, A. M. (2021). Sosialisasi Aplikasi Pembelajaran Jarak Jauh dan Pengembangan Bahan Ajar bagi Dosen, Guru, dan Mahasiswa di Era Pandemi Covid-19. Bima Abdi: Jurnal Pengabdian Masyarakat, 1(1), 30-36. 